Article

\title{
Sustainable Production of Arecanut Husk Ash as Potential Silica Replacement for Synthesis of Silicate-Based Glass-Ceramics Materials
}

\author{
Muhammad Fahmi Anuar ${ }^{1,2}\left(\mathbb{D}\right.$, Yap Wing Fen ${ }^{1,2, *}$, Muhammad Zakwan Azizan ${ }^{1}$, Fida'i Rahmat ${ }^{2}$, \\ Mohd Hafiz Mohd Zaid ${ }^{1}$ (D), Rahayu Emilia Mohamed Khaidir ${ }^{2}$ and Nur Alia Sheh Omar ${ }^{1,2}$ \\ 1 Department of Physics, Faculty of Science, Universiti Putra Malaysia, UPM, \\ Serdang 43400, Selangor, Malaysia; fahmianuar6323@gmail.com (M.F.A.); \\ zakwanazizan@gmail.com (M.Z.A.); mhmzaid@upm.edu.my (M.H.M.Z.); \\ nuralia.upm@gmail.com (N.A.S.O.) \\ 2 Functional Devices Laboratory, Institute of Advanced Technology, Universiti Putra Malaysia, UPM, \\ Serdang 43400, Selangor, Malaysia; fidai.rahmat95@gmail.com (F.R.); \\ rahayuemilia.upm@gmail.com (R.E.M.K.) \\ * Correspondence: yapwingfen@gmail.com
}

check for updates

Citation: Anuar, M.F.; Fen, Y.W.; Azizan, M.Z.; Rahmat, F.; Zaid, M.H.M.; Khaidir, R.E.M.; Omar, N.A.S. Sustainable Production of Arecanut Husk Ash as Potential Silica Replacement for Synthesis of Silicate-Based Glass-Ceramics Materials. Materials 2021, 14, 1141. https://doi.org/10.3390/ma14051141

Academic Editor: Francesco Baino

Received: 23 January 2021

Accepted: 19 February 2021

Published: 28 February 2021

Publisher's Note: MDPI stays neutral with regard to jurisdictional claims in published maps and institutional affiliations.

Copyright: (c) 2021 by the authors. Licensee MDPI, Basel, Switzerland. This article is an open access article distributed under the terms and conditions of the Creative Commons Attribution (CC BY) license (https:// creativecommons.org/licenses/by/ $4.0 /)$.

\begin{abstract}
Arecanut husk (AH) was selected as a material for silica replacement in the synthesis process of glass-ceramics zinc silicate and also the fact that it has no traditional use and often being dumped and results in environmental issues. The process of pyrolysis was carried out at temperature $700{ }^{\circ} \mathrm{C}$ and above based on thermogravimetric analysis to produce arecanut husk ash (AHA). The average purity of the silica content in AHA ranged from $29.17 \%$ to $45.43 \%$. Furthermore, zinc oxide was introduced to AHA and zinc silicate started to form at sintering temperature $700{ }^{\circ} \mathrm{C}$ and showed increased diffraction intensity upon higher sintering temperature of $600{ }^{\circ} \mathrm{C}$ to $1000{ }^{\circ} \mathrm{C}$ based on X-ray diffraction (XRD) analysis. The grain sizes of the zinc silicate increased from $1011 \mathrm{~nm}$ to $3518 \mathrm{~nm}$ based on the morphological studies carried out by field emission scanning electron microscopy (FESEM). In addition, the optical band gap of the sample was measured to be in the range from $2.410 \mathrm{eV}$ to $2.697 \mathrm{eV}$ after sintering temperature. From the data, it is believed that a cleaner production of low-cost zinc silicate can be achieved by using arecanut husk and have the potential to be used as phosphors materials.
\end{abstract}

Keywords: arecanut ash; $\mathrm{ZnO} ; \mathrm{SiO}_{2}$; zinc silicate; optical; structural; willemite

\section{Introduction}

Arecanut is a well-known tropical crop that belongs to Arecaceae family that are commercially and socially important in south-east Asian countries. India, Sri Lanka, Bangladesh, Malaysia, Indonesia, and Philippines are the main countries that grow arecanut [1]. The arecanut husk $(\mathrm{AH})$ constitutes about $65-80 \%$ of the total weight and volume of the fruit. Generally, the arecanut is used for chewing in some Asian countries and the husk of the arecanut fruits is removed due to it has no traditional use. Occasionally, $\mathrm{AH}$ is being used as fuel for the processing of the nut. As a result, large heaps of the $\mathrm{AH}$ biomass caused environmental issues due to the lack of proper disposal techniques for the waste husks. Hence, the rising issues due to the growth of arecanut industry have inspired researchers to find alternative uses for the waste $\mathrm{AH}$.

Several studies had been conducted to utilize this renewable biomass for different applications. The arecanut husk has been used as a supportive cementitious material [2], adsorption of malachite green from aqueous solutions [3], ethanol production [4], as natural reinforcement in biodegradable polymer composites [5], and was also studied in domestic wastewater treatment [6]. Despite that, there are only a few related researches of AH that used it as a source of silica in glass-ceramics applications. 
In recent years, the development of glass-ceramics has attracted a lot of attention from researchers due to its producibility from waste materials. Due to its compositions, $\mathrm{AH}$ ash is considered to have the potential in the production of silicate-based glass-ceramics. The major component found in $\mathrm{AH}$ ash is silica along with some metallic oxide such as alumina, magnesium oxide, and potassium oxide [2]. In addition to being environmentally friendly, the production of glass-ceramics derived from waste materials is also low-cost and thus reduces the dependency on natural resources in glass-ceramics production.

Zinc silicate is also known as willemite is a glass-ceramics material that has been identified as a capable host matrix for doping with various transition metals or rareearth ions for their luminescence properties $[7,8]$. It has been used widely as a phosphor in fluorescent lamps, television, display, and lighting devices [9]. Due to its great luminescence properties, researchers are more focused to develop a new method to synthesis zinc silicatebased glass-ceramics for potential phosphors materials.

In the present work, the preparation of zinc silicate from waste AH has been described and the sintering effects on structural and optical properties of the glass-ceramics materials are also investigated.

\section{Experimental Procedure}

\subsection{Preparation of Arecanut}

In this experiment, arecanut husks were subjected to pyrolysis. Arecanut waste (Figure 1) was collected from a local farm in Selangor, Malaysia. The husk was cleaned by distilled water and dried up in the oven at $70^{\circ} \mathrm{C}$ for $24 \mathrm{~h}$. This precaution step was carried out to avoid any contamination, removed the unwanted residues, and kill all the insects that have been living in the husk. After that, the husk was burned in the electrical furnace at $700{ }^{\circ} \mathrm{C}, 800{ }^{\circ} \mathrm{C}$, and $900{ }^{\circ} \mathrm{C}$ to determine the optimum temperature needed to extract the highest percentage of $\mathrm{SiO}_{2}$ from arecanut husk. Furthermore, the powder was then sieved into fine powder of approximately $45 \mu \mathrm{m}$.

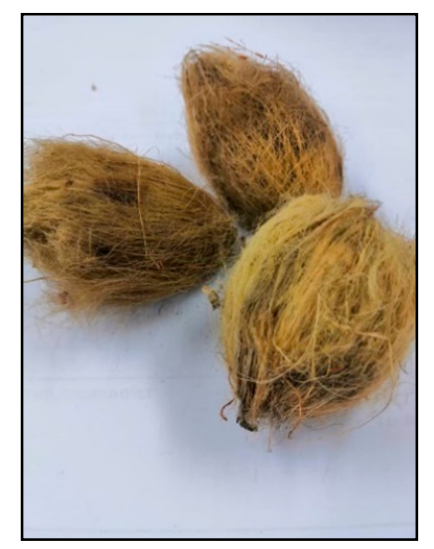

Figure 1. Cleaned arecanut fruit collected from a local farm.

\subsection{Synthesis of Zinc Silicate}

To prepare $\mathrm{Zn}_{2} \mathrm{SiO}_{4}$ based arecanut waste silica, $10 \mathrm{~g}$ batch of the mixture first weighed using digital weighing machine. The mixture powder then thoroughly mixed via milling process using a ball milling jar for $4 \mathrm{~h}$. After the milling process, the mixture was melted in an alumina crucible at $1450{ }^{\circ} \mathrm{C}$ in the air with a heating rate of $10^{\circ} \mathrm{C} / \mathrm{min}$ for $2 \mathrm{~h}$ in an electrically heated furnace. The molten mixture was immediately poured into water to obtain a transparent glass fritz. The glass fritz was naturally dried at room temperature for 1 day and later crushed and sieved into fine powder of about $45 \mu \mathrm{m}$. Then, the sample was sintered at $600-1000{ }^{\circ} \mathrm{C}$ for further characterization. 


\subsection{Characterization}

In this work, thermogravimetry analysis (TGA) was carried out by using a Mettler Toledo TGA/DSC 1HT (Mettler Toledo, Küsnacht, Switzerland) to determine the thermal stability of the arecanut husk in the presence of oxygen gas. Quantitative measurement of the sample's elemental composition was carried out using X-ray fluorescence (XRF) XRF-EDX-720/7000 spectroscopy (Shimadzu, Kyoto, Japan). Furthermore, the phase identification of the sample was analysed by using X-ray diffraction (XRD) Phillips X'Pert High Pro PANanalytical Diffractometer (Malvern PanAnalytical, Almelo (Netherland), and Malvern (UK)). The morphological structure of the sample was observed under the field emission scanning electron microscopy (FESEM), Nova NanoSEM 30 (FEI, Hillsboro, OR, USA) under $25,000 \times$ magnification level. In addition, the absorbance properties of the sample were analysed by UV-3600 Shimadzu (Shimadzu, Kyoto, Japan). The overall methodology of the experiment is illustrated in Figure 2.



Figure 2. The methodology of producing zinc silicate from waste arecanut husk. 


\section{Results and Discussion}

\subsection{Arecanut Husk (AH)}

Thermal analysis of the arecanut husk was conducted by using thermogravimetry analysis (TGA) at a temperature range of $27-1000{ }^{\circ} \mathrm{C}$. A graph of temperature against weight was plotted as shown in Figure 3. The percentage of weight loss at each stage can be determined from the plotted graph. The initial stage (I) of the weight loss corresponds to the release of moisture from the arecanut husk. At this stage, about $8.97 \%$ of the total weight of arecanut husk decomposed due to loss of water content and light volatile compounds [10-12]. Afterward, the second stage (II) of weight loss occurred in the range of $200^{\circ} \mathrm{C}-315^{\circ} \mathrm{C}$. Above $200^{\circ} \mathrm{C}$, the thermal resistance of agriculture waste gradually [13]. About $44.50 \%$ of the weight of $\mathrm{AH}$ was loss at this stage due to the decomposition of hemicellulose [14]. Stage (III) occurred at temperature between 315 and $430{ }^{\circ} \mathrm{C}$ and the arecanut husk undergone about $40.77 \%$ weight loss, which is associated with the decomposition of cellulose. Stage (II) and (III) of the TGA graph undergone rapid weight loss was due to the devolatilization of organic compounds of hemicellulose and cellulose [11,15]. Decomposition of hemicellulose occurred at a lower temperature $\left(180-340{ }^{\circ} \mathrm{C}\right)$ and cellulose $\left(230-450{ }^{\circ} \mathrm{C}\right)$ [14]. At this stage (IV), AH produces about $5.76 \%$ of ash after the pyrolysis process. The stabilization of mass loss for AH at stage (IV) specifies the complete burning process of volatile components and proposes a temperature above $600{ }^{\circ} \mathrm{C}$ for the pyrolysis process for char formations. To sum up, the TGA was carried out and the weight degradation analysis of the $\mathrm{AH}$ was discussed and deemed suitable to be used in this work.

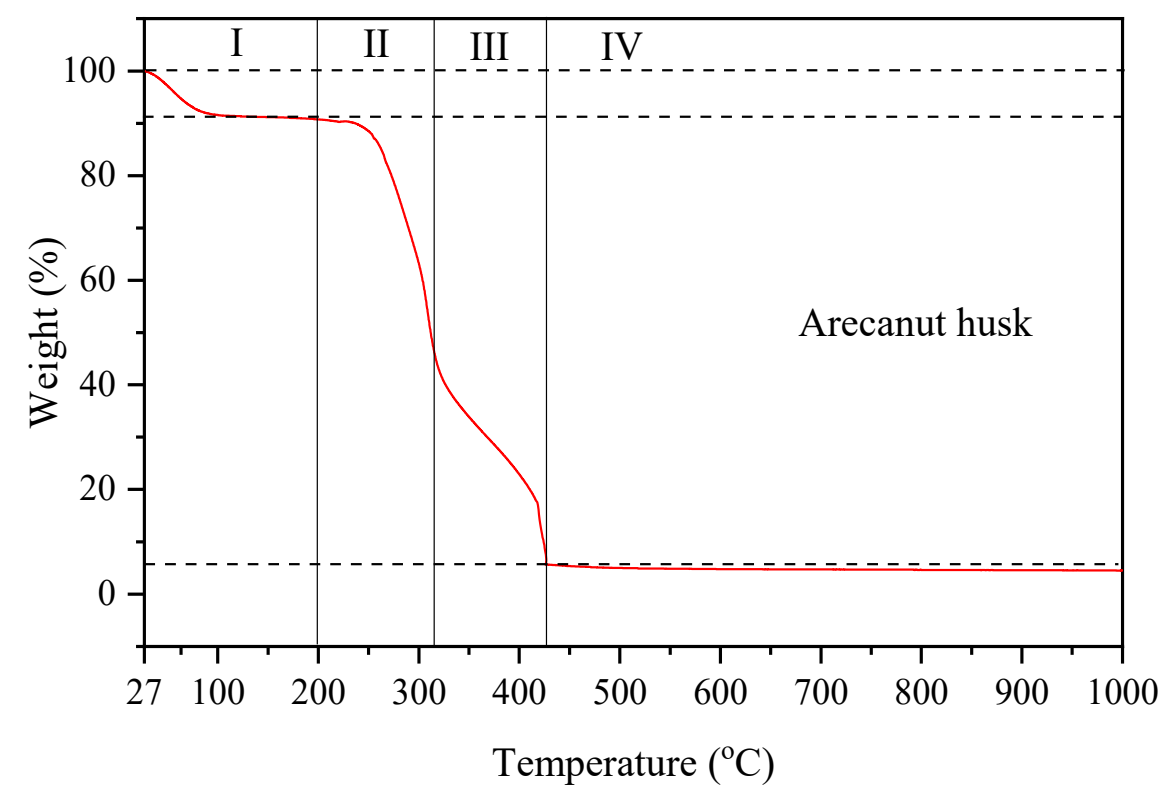

Figure 3. Thermogravimetry analysis (TGA) of arecanut husk.

\subsection{Arecanut Husk Ash}

The elemental analysis of arecanut husk ash (AHA) pyrolyzed at different temperature was determined with XRF as in Table 1. Arecanut ash sample was pyrolysed at three different temperatures for $2 \mathrm{~h}$ to determine the optimum silica composition in the ash. From the table, it is obvious that predominant $\mathrm{SiO}_{2}$ elements was detected at temperature range from 700 to $900{ }^{\circ} \mathrm{C}$. Other elements such as $\mathrm{Al}_{2} \mathrm{O}_{3}, \mathrm{SiO}_{2}, \mathrm{P}_{2} \mathrm{O}_{5}, \mathrm{Cl}, \mathrm{K}_{2} \mathrm{O}, \mathrm{CaO}, \mathrm{Fe}_{2} \mathrm{O}_{3}$, and $\mathrm{ZnO}$ were also detected in the AHA as the minority elements. AH that was pyrolyzed at $900{ }^{\circ} \mathrm{C}$ shows the highest percentage of $\mathrm{SiO}_{2}$ which is $45.43 \%$ and thus suitable for further synthesis of zinc silicate based glass-ceramics. 
Table 1. Elemental composition of arecanut husk ash (AHA) at different sintering temperature.

\begin{tabular}{cccc}
\hline \multirow{2}{*}{ Elements } & \multicolumn{3}{c}{ Percentages of Compositions (\%) } \\
\cline { 2 - 4 } & $\mathbf{7 0 0}{ }^{\circ} \mathbf{C}$ & $\mathbf{8 0 0}{ }^{\circ} \mathbf{C}$ & $\mathbf{9 0 0}{ }^{\circ} \mathbf{C}$ \\
\hline $\mathrm{Al}_{2} \mathrm{O}_{3}$ & 0.64 & 2.00 & 0.00 \\
$\mathrm{SiO}_{2}$ & 29.17 & 44.14 & 45.43 \\
$\mathrm{P}_{2} \mathrm{O}_{5}$ & 26.91 & 14.64 & 18.62 \\
$\mathrm{Cl}$ & 0.75 & 0.33 & 0.30 \\
$\mathrm{~K}_{2} \mathrm{O}$ & 16.65 & 7.28 & 10.35 \\
$\mathrm{CaO}$ & 20.07 & 13.99 & 14.16 \\
$\mathrm{Fe}_{2} \mathrm{O}_{3}$ & 4.02 & 13.57 & 9.62 \\
$\mathrm{ZnO}$ & 0.57 & 0.66 & 0.54 \\
\hline
\end{tabular}

Figure 4 illustrates the FESEM images for arecanut ash burned at different temperatures, which are 700 to $900{ }^{\circ} \mathrm{C}$ under $25,000 \times$ magnification. As shown in the figures, the results presented that all the samples have irregular medium-sized particles distribution with crushed shape structure. FESEM observation of AHA showed aggregation and irregularity in shape and size [16], which is different in comparison with coconut husk ash (CHA) that showed rod-like structure [17].

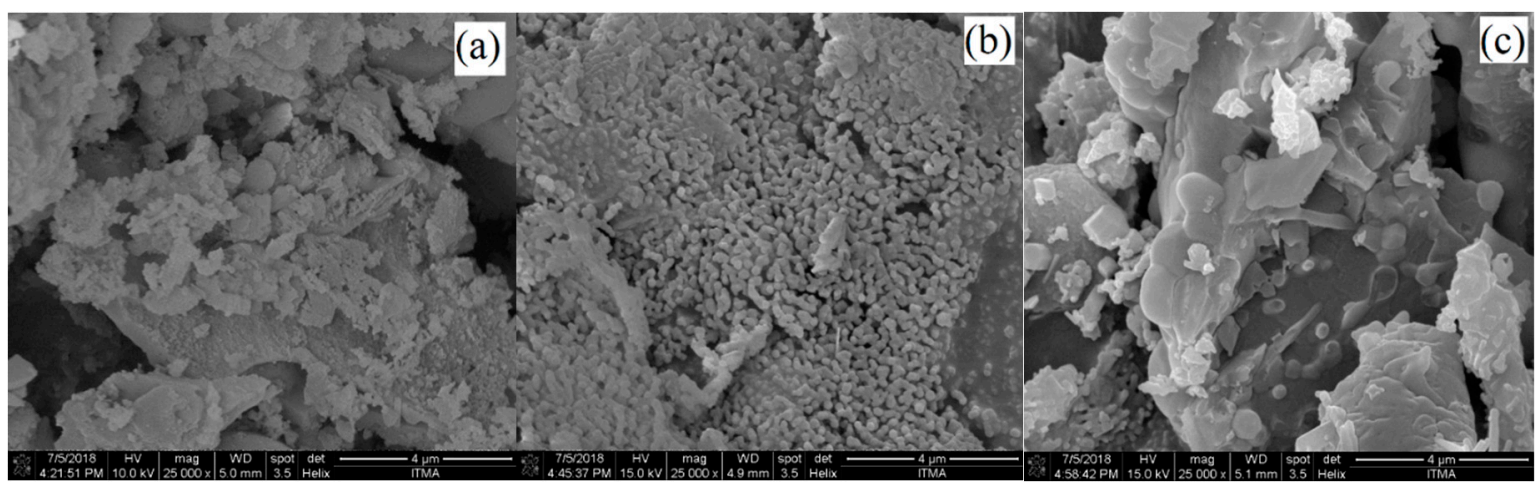

Figure 4. FESEM images of arecanut ash burned at (a) $700^{\circ} \mathrm{C}$ (b) $800^{\circ} \mathrm{C}$ (c) $900{ }^{\circ} \mathrm{C}$ under magnification of $25,000 \times$.

\subsection{Zinc Silicate}

The crystalline or amorphous nature of the samples was analysed using XRD. Figure 5 consists of XRD patterns of the sample sintered at various sintering temperatures from $600{ }^{\circ} \mathrm{C}$ to $1000{ }^{\circ} \mathrm{C}$ for $4 \mathrm{~h}$. The unsintered glass sample (RT) was presented with no diffraction peaks, which indicate the amorphous nature of the sample. Besides, at $600{ }^{\circ} \mathrm{C}$, the sample was still in amorphous structure due to the low sintering temperature that does not induced the crystal growth of the sample. The crystalline process begins at temperatures higher than $700^{\circ} \mathrm{C}$. It was noticed that the characteristics peak of the sample at this temperature shows the lowest intensity that indicated the sample has poor crystallinity. Three major peaks appeared indicating the presence of $\mathrm{Zn}_{2} \mathrm{SiO}_{4}$ and according to Inorganic Structural Database (ICSD) no. 00-037-1485, the $\mathrm{Zn}_{2} \mathrm{SiO}_{4}$ has an orthorhombic crystal structure same reported in previous research [18-21]. Besides that, diffraction pattern that resembled $\mathrm{ZnO}$ (ICSD 00-036-1451) was also found at this temperature.

At $800{ }^{\circ} \mathrm{C}$, more elements of $\mathrm{Zn}_{2} \mathrm{SiO}_{4}$ started to appear at $27.30^{\circ}$. Moreover, as the temperature increased to $900^{\circ} \mathrm{C}$, strong and high-intensity peaks of rhombohedral $\mathrm{Zn}_{2} \mathrm{SiO}_{4}$ appeared and fewer $\mathrm{ZnO}$ peaks were observed [22]. The formation of the $\mathrm{Zn}_{2} \mathrm{SiO}_{4}$ has the highest peak at this temperature compared to other sintering temperatures. It was explained that $\mathrm{ZnO}$ is the dominant diffusing species in $\mathrm{ZnO} / \mathrm{Al}_{2} \mathrm{O}_{3}$ couple at higher temperatures greater than $700{ }^{\circ} \mathrm{C}[23]$ and it was also believed that the same result can be obtained in the case of $\mathrm{ZnO} / \mathrm{SiO}_{2}$ due to the similarities between $\mathrm{SiO}_{2}$ and $\mathrm{Al}_{2} \mathrm{O}_{3}$ such as amorphous nature and large optical bandgap [24]. For the sample sintered at $1000{ }^{\circ} \mathrm{C}$, the 
zinc silicate phase have the highest peak intensity in comparison to other temperatures. At this temperature, peaks identified as $\mathrm{ZnO}$ still exists at $36.75^{\circ}$. This phenomenon indicated that at $1000{ }^{\circ} \mathrm{C}$ sintering temperature, the formation of $\mathrm{Zn}_{2} \mathrm{SiO}_{4}$ was higher due to the increase in crystal growth, and the peaks become more intensified due to the increasing crystallinity of the sample [25].

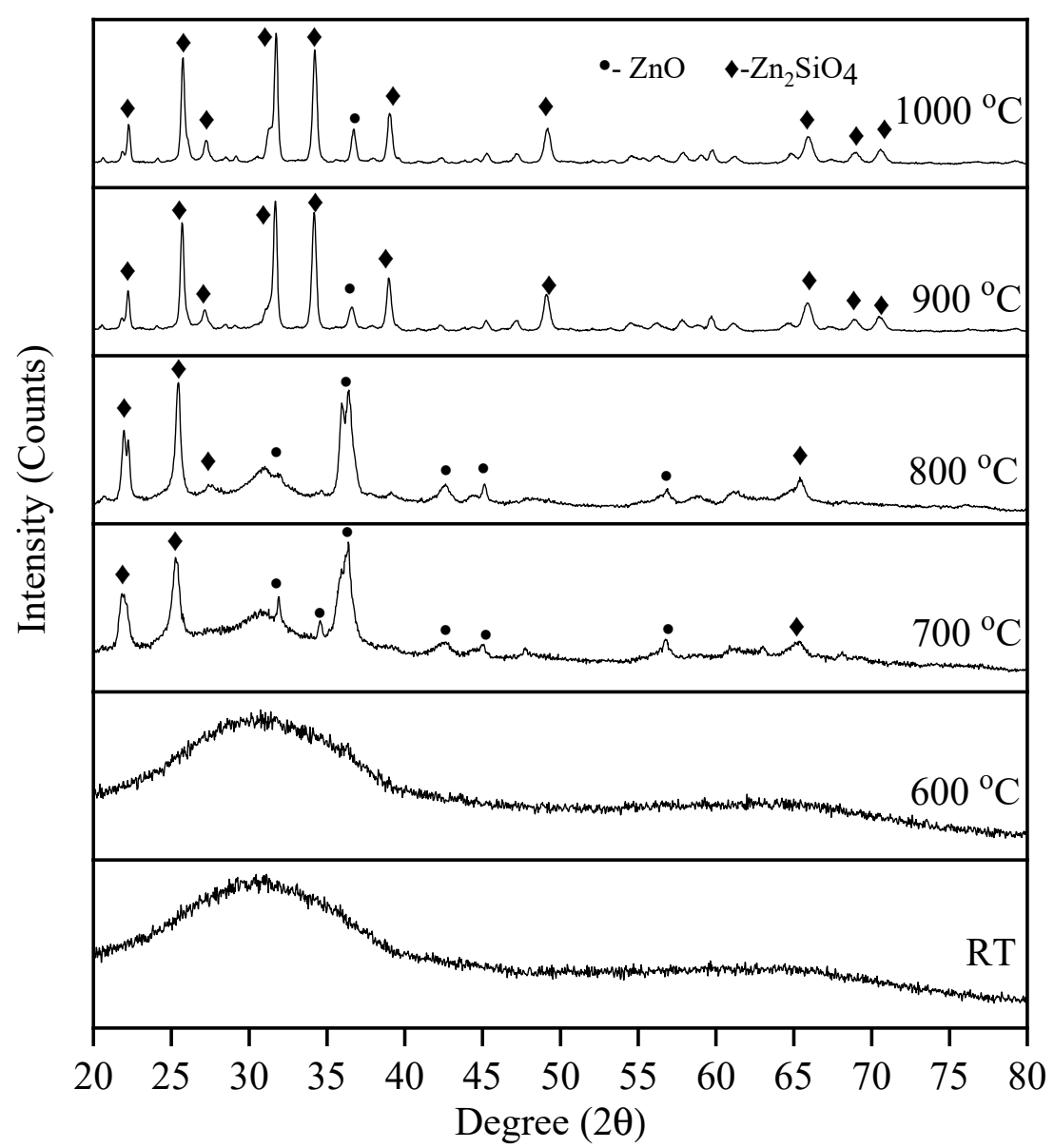

Figure 5. XRD patterns of $\mathrm{Zn}_{2} \mathrm{SiO}_{4}$ sintered at different temperatures.

FESEM analysis was performed to study the shape, size, and morphology of the $\mathrm{Zn}_{2} \mathrm{SiO}_{4}$ samples. FESEM microstructures of the sintered samples are presented in Figure 6a- $\mathrm{f}$ under magnification of $25,000 \times$. From the FESEM micrographs, it was observed that the prepared sample was not uniform and consisted of irregular particle size distribution with the average grain sizes of $813 \mathrm{~nm}$. After sintered at $600^{\circ} \mathrm{C}$, the sample was observed to gain in sizes with the average grain sizes measured to be $895 \mathrm{~nm}$. When the sintered temperature increased to $700-1000{ }^{\circ} \mathrm{C}$, the morphology of the $\mathrm{Zn}_{2} \mathrm{SiO}_{4}$ glass-ceramic became granular and show more homogeneous distribution [26]. Furthermore, samples sintered at $700{ }^{\circ} \mathrm{C}$ to $1000{ }^{\circ} \mathrm{C}$ showed larger grain sizes with an increase in sintering temperature measured from 1011 to $3518 \mathrm{~m}$. Thus, it is confirmed that the grain size of the samples showed increasing trends as the sintering temperatures increased due to the increase in its growth rate and crystallinity $[27,28]$. The relations between sintering temperature and the average grain sizes of the samples are illustrated in Figure 7. 

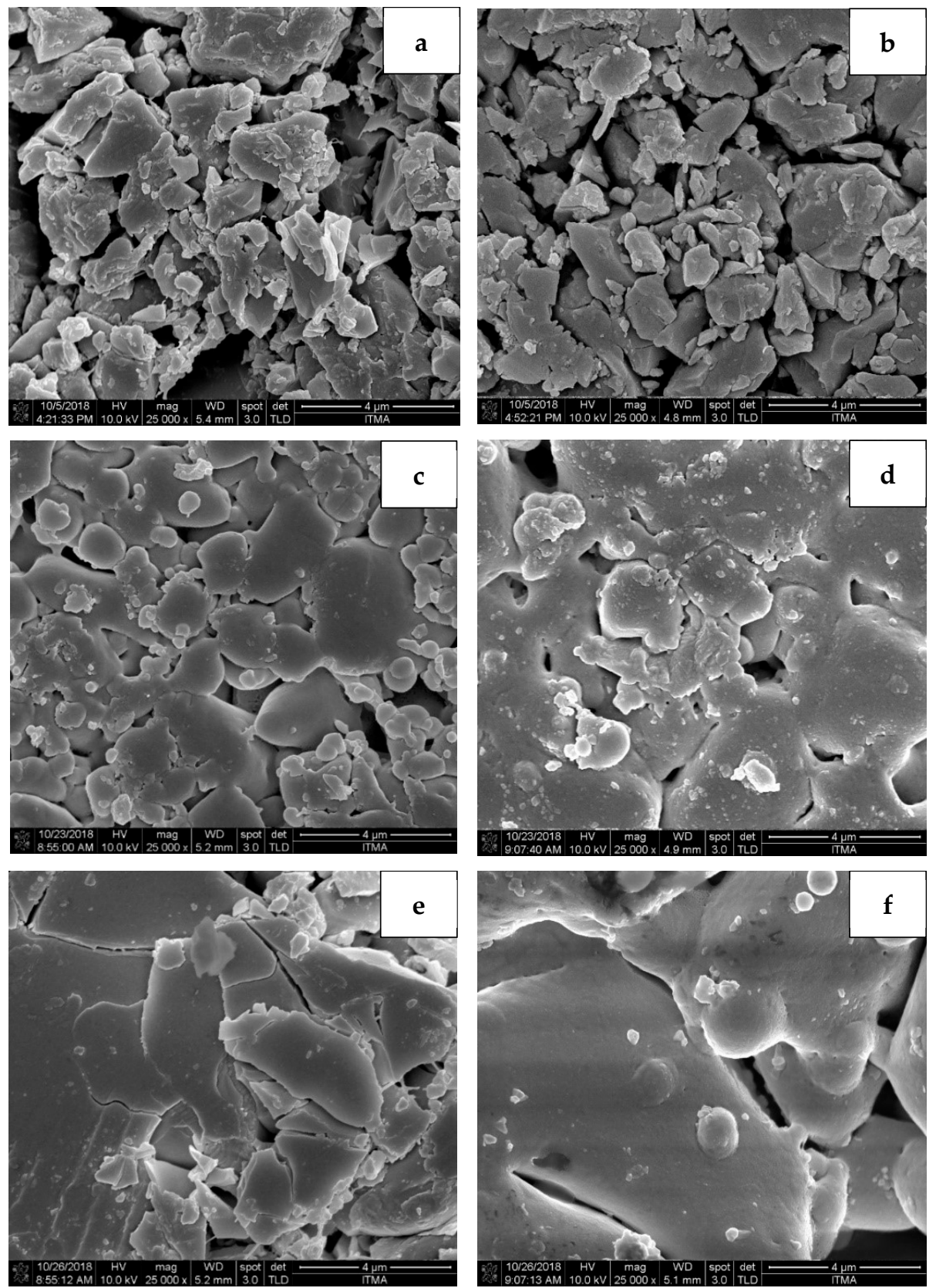

Figure 6. The microstructure images of zinc silicate sintered at different sintering temperature of (a) RT, (b) 600, (c) 700, (d) 800, (e) 900, and (f) $1000^{\circ} \mathrm{C}$.

UV-Visible spectroscopy measurement for the glass-ceramics samples was performed at room temperature in spectral regions between 220 and $800 \mathrm{~nm}$. The absorption spectra of $\mathrm{Zn}_{2} \mathrm{SiO}_{4}$ sintered at different sintering temperatures are shown in Figure 8. According to the result presented, the curve showed that intensive absorption occurred in the range of 200-300 nm due to the scattering by $\mathrm{Zn}_{2} \mathrm{SiO}_{4}$ nanocrystal similar as reported by [29]. It indicates that the highest absorbance intensity occurs when the sintering temperature was at $700{ }^{\circ} \mathrm{C}$ and $800^{\circ} \mathrm{C}$, meanwhile at $1000^{\circ} \mathrm{C}$, the absorption intensities were low due to the formation of pure willemite phase, which distinguishes the $\mathrm{ZnO}$ hexagonal structure [24]. Based on XRD data, $\mathrm{ZnO}$ hexagonal phase formed when the sample was heated at $700{ }^{\circ} \mathrm{C}$ and $800{ }^{\circ} \mathrm{C}$ due to the fact that the absorbance of the sample at $700{ }^{\circ} \mathrm{C}$ and $800^{\circ} \mathrm{C}$ were the highest compared to other temperatures. At higher temperature of $900{ }^{\circ} \mathrm{C}$ to $1000{ }^{\circ} \mathrm{C}$, the absorbance decreases due to the increase in the willemite phase intensity [30]. Lastly, the 
absorbance of unsintered temperature and $600{ }^{\circ} \mathrm{C}$ sintering temperature has low intensity because the samples still in amorphous state.

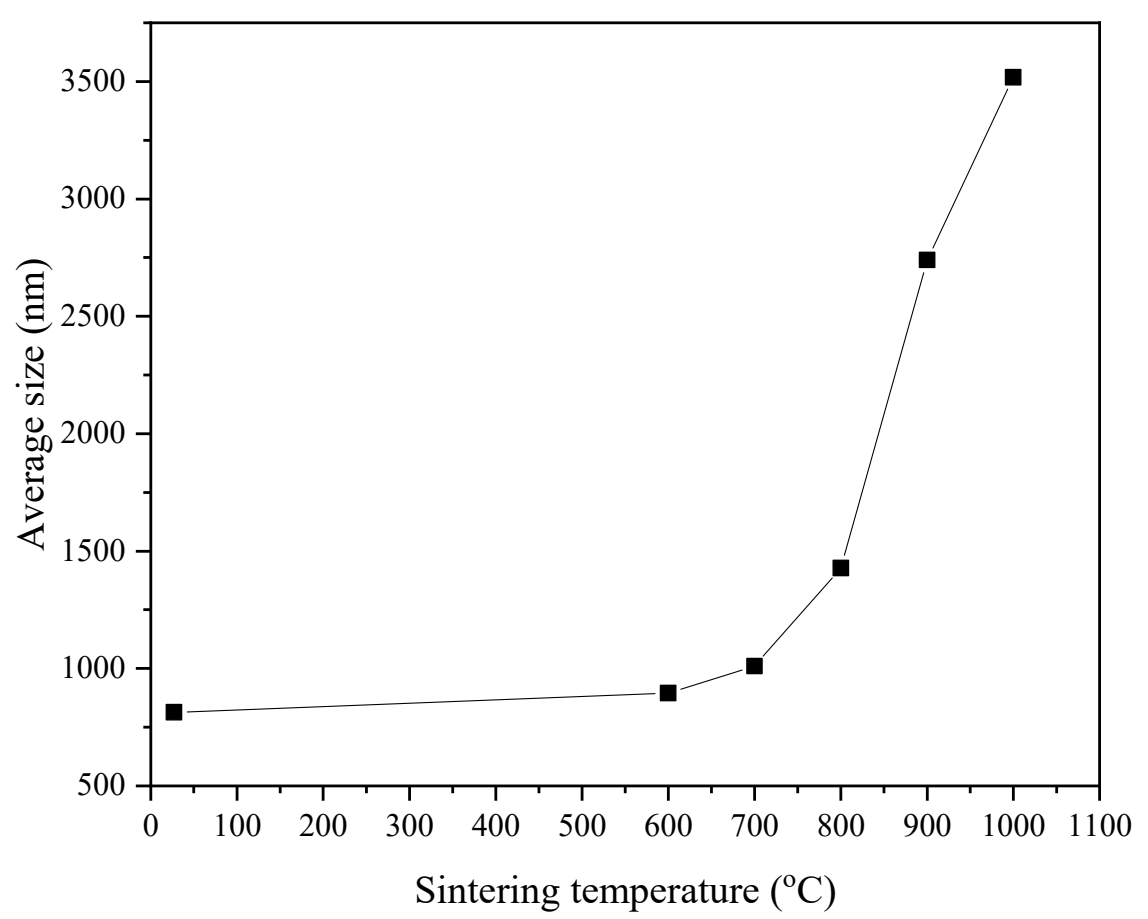

Figure 7. The average grain size of zinc silicate sintered at different sintering temperatures of RT, 600, $700,800,900$, and $1000^{\circ} \mathrm{C}$.

To determine the optical band gap of various samples were different, the graph of $(\alpha h v)^{n}$ versus $h v$ was plotted. The relation between the absorption coefficient and photon energy can be related by using Beer-Lambert Law [31] as in Equation (1).

$$
\alpha=\frac{k\left[h v-E_{\text {gap }}\right]^{n}}{h v}
$$

Equation (1) can be rearranged into:

$$
(\alpha h v)^{1 / n}=h v-E_{\text {gap }}
$$

where $\alpha$ is the absorbance coefficient, $h$ is plank constant, $v$ is the frequency, $n$ is the transition, and $E_{\text {gap }}$ is the optical band gap [32]. In this work, $n=1 / 2$ was inserted into Equation (2) to form Equation (3)

$$
(\alpha h v)^{2}=h v-E_{\text {gap }}
$$

From the graph, each best fit line was drawn until it reaches the xaxis to determine the optical band gap. To investigate the energy band gap for each sample, a graph was plotted for each one of different sintering temperatures. Figure 9 shows the graph of energy band gap for the direct transition. Referring to that figure, the energy band gap of unsintered $\mathrm{Zn}_{2} \mathrm{SiO}_{4}$ was $2.847 \mathrm{eV}$. In the visible light region, the zinc silicate displayed higher peaks of absorption due to Van Hove singularities. Different sintering temperatures caused the zinc silicate experienced significant changes to the Van Hove peaks. Next, the energy band gap for the temperature at $600{ }^{\circ} \mathrm{C}$ and $700{ }^{\circ} \mathrm{C}$ of the sample were $2.697 \mathrm{eV}$ and $2.660 \mathrm{eV}$, respectively. The energy band gap dropped slightly at temperature $800{ }^{\circ} \mathrm{C}(2.474 \mathrm{eV})$ and $900{ }^{\circ} \mathrm{C}(2.410 \mathrm{eV})$ but it increased at $1000{ }^{\circ} \mathrm{C}$, which was $2.530 \mathrm{eV}$. In comparison, the band gap value of 2.970 to $4.540 \mathrm{eV}[8,17,33-35]$ was obtained for zinc silicate from previous 
research that indicated the zinc silicate has flexible band gap value (optical properties) that were influenced by different steps in the synthesis process.

Overall, the decreasing trend of the optical band gap was observed for both graphs as the temperature keeps increasing to $900{ }^{\circ} \mathrm{C}$ but increased after being heated at $1000^{\circ} \mathrm{C}$. The increase in the energy band gap was due to the improvement of the sample crystallinity and quantum size effect [36]. The energy band gap tends to decrease as the temperature increased due to band gap narrowing and smaller separation distance of an electron-hole [37].

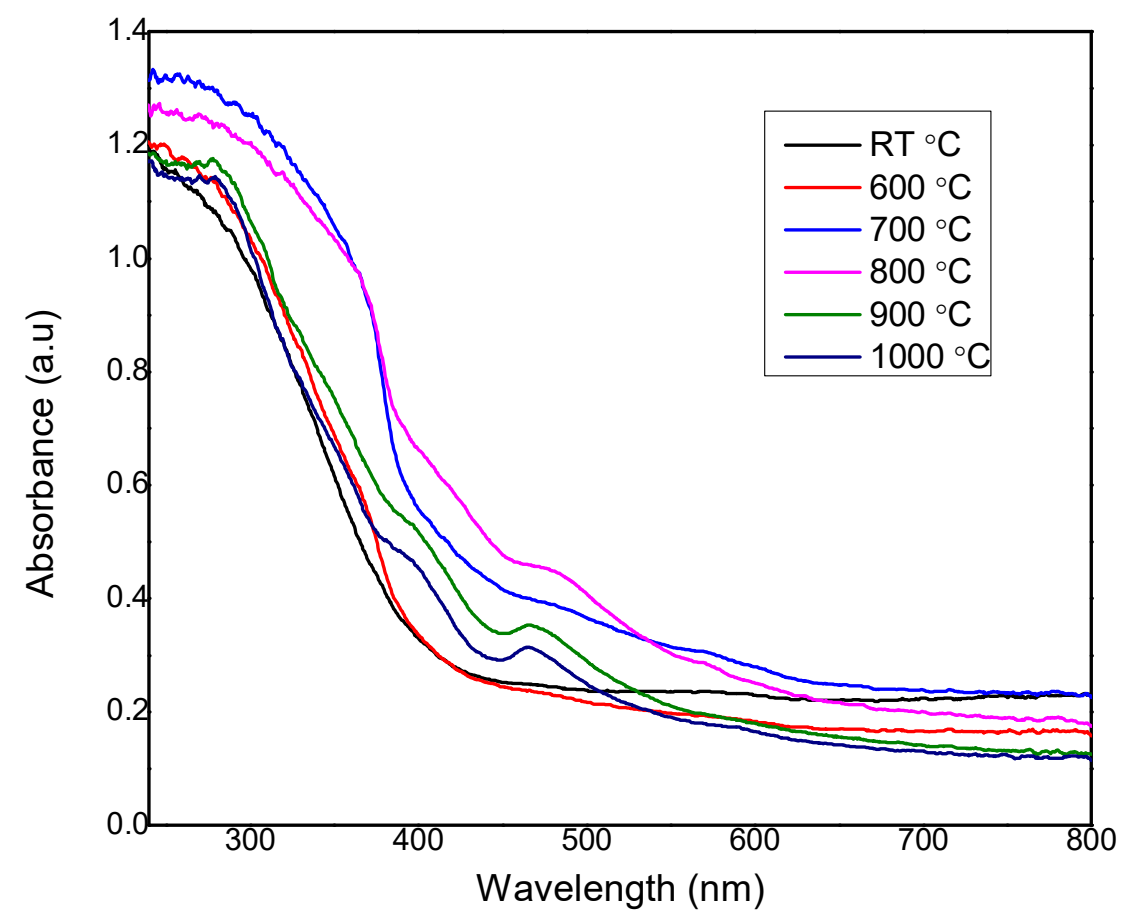

Figure 8. The absorbance spectrum of zinc silicate sintered at different sintering temperatures of RT, $600,700,800,900$, and $1000^{\circ} \mathrm{C}$.

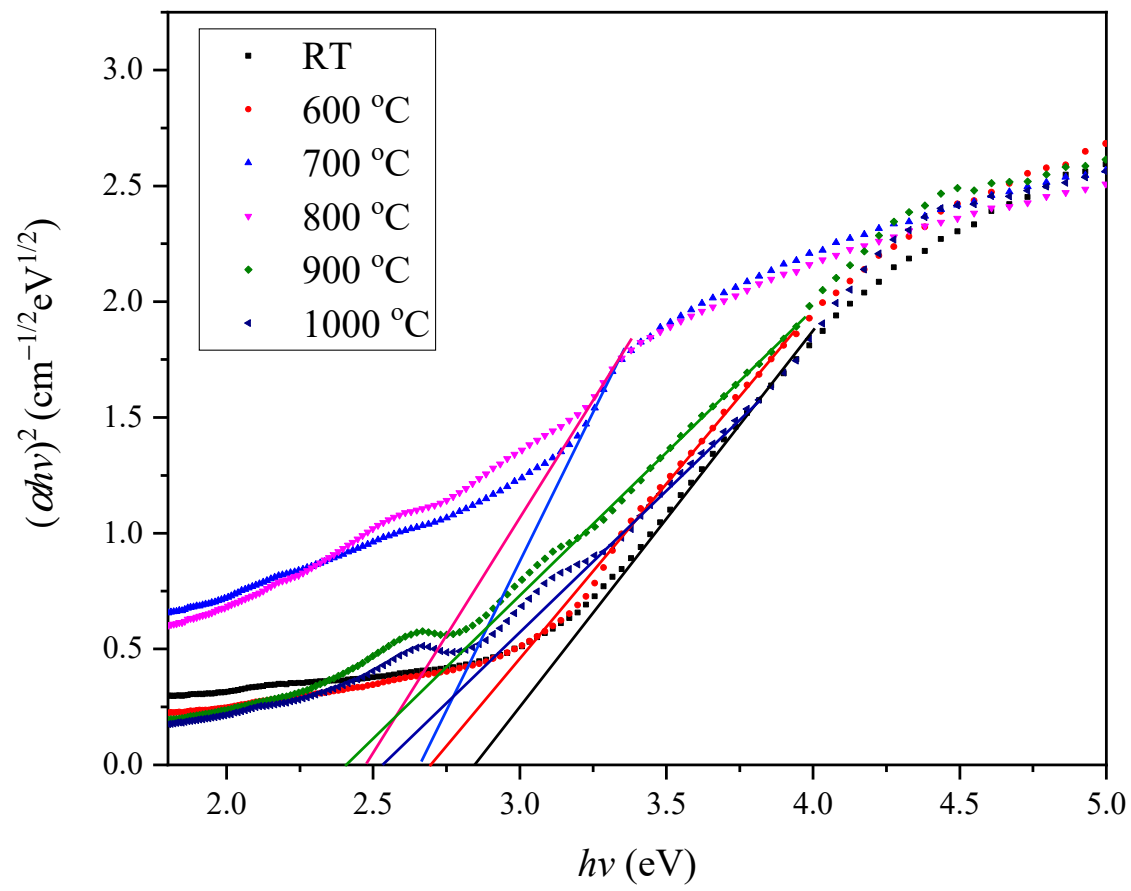

Figure 9. The optical band gap of zinc silicate sintered at different sintering temperatures of RT, 600, $700,800,900$, and $1000{ }^{\circ} \mathrm{C}$. 
Altogether, research data were analysed and discussed with detail. Without a doubt, $\mathrm{AH}$ was indeed a suitable material as a substitute material for silica. Both structural and optical properties of the synthesized zinc silicate from the AH exhibit good properties to be used in optical applications especially as phosphors material.

\section{Conclusions}

In this investigation, the arecanut husk ( $\mathrm{AH})$ was explored as it has great potential to be used as silica replacement. It is estimated that the average purity of $\mathrm{SiO}_{2}$ in $\mathrm{AHA}$ ranged from $29.17 \%$ to $45.43 \%$ with irregular shape and size distribution. Furthermore, zinc silicate was successfully prepared by adding AHA and $\mathrm{ZnO}$ and shows high diffraction intensity that indicates the sample have high crystallinity at higher temperature. After the sintering process, the sample was measured to have increased in sizes up to $3517.8 \pm 3.08 \mathrm{~nm}$ at $1000{ }^{\circ} \mathrm{C}$. In addition, the optical band gap of the sample decreased upon higher temperature but at $1000{ }^{\circ} \mathrm{C}$ the band gap increased to $2.530 \mathrm{eV}$ due to improve in crystallinity. Altogether, this works emphasis the potential of $\mathrm{AH}$ as a silica replacement and as well as the possibility to be used as a phosphor material.

Author Contributions: Data curation, M.F.A. and F.R. formal analysis, M.F.A. and M.Z.A.; investigation, M.F.A., N.A.S.O., and R.E.M.K.; methodology, Y.W.F., and R.E.M.K.; supervision, Y.W.F. and M.H.M.Z; writing—original draft, M.F.A.; writing—review and editing, Y.W.F. All authors have read and agreed to the published version of the manuscript.

Funding: The research received the financial support from the Malaysian Ministry of Education (MOE) and Universiti Putra Malaysia (UPM) through the Putra Grant 9642800.

Institutional Review Board Statement: Not applicable.

Informed Consent Statement: Not applicable.

Data Availability Statement: The data presented in this study are available on request from the corresponding author.

Acknowledgments: The authors gratefully acknowledge the financial support for this study from the Malaysian Ministry of Education (MOE) and Universiti Putra Malaysia (UPM). The laboratory facilities provided by the Institute of Advanced Technology and Faculty of Science, Universiti Putra Malaysia, are also acknowledged.

Conflicts of Interest: The authors declare no conflict of interest.

\section{References}

1. Paramesh, V.; Arunachalam, V.; Nikkhah, A.; Das, B.; Ghnimi, S. Optimization of energy consumption and environmental impacts of arecanut production through coupled data envelopment analysis and life cycle assessment. J. Clean. Prod. 2018, 203, 674-684. [CrossRef]

2. Das, N.; Singh, S. The potential of arecanut husk ash as supplementary cementitious material. Conrete Res. Lett. 2015, 6, 126-135.

3. Basker, A.; Syed Shabudeen, P.S.; Daniel, S.; Vignesh Kumar, P. Adsorptive removal of malachite green from aqueous solution using areca husk carbon. Rasayan J. Chem. 2014, 7, 1-15.

4. Prasad, S.; Singh, A.; Joshi, H.C. Ethanol as an alternative fuel from agricultural, industrial and urban residues. Resour. Conserv. Recycl. 2007, 50, 1-39. [CrossRef]

5. Yusriah, L.; Sapuan, S.M.; Zainudin, E.S.; Mariatti, M. Exploring the potential of betel nut husk fiber as reinforcement in polymer composites: Effect of fiber maturity. Procedia Chem. 2012, 4, 87-94. [CrossRef]

6. Shivakumaraswamy, G.R.; Mahalingegowda, R.M.; Vinod, A.R. Domestic wastewater treatment in reactors filled with areca husk fiber and pebble bed. Pollution 2013, 57, 14064-14066.

7. Omar, N.A.S.; Fen, Y.W.; Matori, K.A. Photoluminescence properties of $\mathrm{Eu}^{3+}$-doped low cost zinc silicate based glass ceramics. Optik 2016, 127, 3727-3729. [CrossRef]

8. Khaidir, R.E.M.; Fen, W.Y.; Zaid, M.H.M.; Matori, K.A.; Omar, N.A.S.; Anuar, M.F.; Wahab, S.A.A.; Azman, A.Z.K. Optical band gap and photoluminescence studies of $\mathrm{Eu}^{3+}$-doped zinc silicate derived from waste rice husks. Optik 2019, 182, 486-495. [CrossRef]

9. Takesue, M.; Hayashi, H.; Smith, R.L. Thermal and chemical methods for producing zinc silicate (willemite): A review. Prog. Cryst. Growth Charact. Mater. 2009, 55, 98-124. [CrossRef] 
10. Anuar, M.F.; Fen, Y.W.; Matori, K.A.; Zaid, M.H.M. The physical and optical studies of crystalline silica derived from green synthesis of coconut husk ash. Appl. Sci. 2020, 10, 2128. [CrossRef]

11. Gokul, P.V.; Singh, P.; Singh, V.P.; Sawarkar, A.N. Thermal behavior and kinetics of pyrolysis of areca nut husk. Energy Sources, Part A Recover. Util. Environ. Eff. 2019, 41, 2906-2916.

12. Alves, R.H.; Reis, T.V.D.S.; Rovani, S.; Fungaro, D.A. Green synthesis and characterization of biosilica produced from sugarcane waste ash. J. Chem. 2017, 2017, 1-9. [CrossRef]

13. Prithivirajan, R.; Jayabal, S.; Sundaram, S.K.; Sangeetha, V. Hybrid biocomposites from agricultural residues: Mechanical, water absorption and tribological behaviors. J. Polym. Eng. 2016, 36, 663-671. [CrossRef]

14. Mishra, R.K.; Mohanty, K. Pyrolysis kinetics and thermal behavior of waste sawdust biomass using thermogravimetric analysis. Bioresour. Technol. 2018, 251, 63-74. [CrossRef] [PubMed]

15. Mansaray, K.G.; Ghaly, A.E. Determination of kinetic parameters of rice husks in oxygen using thermogravimetric analysis. Biomass Bioenerg. 1999, 17, 19-31. [CrossRef]

16. Rao, D.S.; Raju, P.S.; Rao, B.S.; Murthy, K.V.R. Luminescent studies of $\mathrm{Zn}_{2} \mathrm{Sio}_{4}: \mathrm{Mn}(1.1 \%)$, $\mathrm{Eu}(1.5 \%)$ phosphor. Int. J. Lumin. Its Appl. 2014, 4, 104-106.

17. Anuar, M.F.; Fen, Y.W.; Zaid, M.H.M.; Matori, K.A.; Khaidir, R.E.M. Synthesis and structural properties of coconut husk as potential silica source. Results Phys. 2018, 11, 1-4. [CrossRef]

18. Khaidir, R.E.M.; Fen, Y.W.; Zaid, M.H.M.; Matori, K.A.; Omar, N.A.S.; Anuar, M.F.; Wahab, S.A.A.; Azman, A.Z.K. Exploring $\mathrm{Eu}^{3+}$-doped $\mathrm{ZnO}-\mathrm{SiO}_{2}$ glass derived by recycling renewable source of waste rice husk for white-LEDs application. Results Phys. 2019, 15, 102596. [CrossRef]

19. Zhang, Q.Y.; Pita, K.; Kam, C.H. Sol-gel derived zinc silicate phosphor films for full-color display applications. J. Phys. Chem. Solids 2003, 64, 333-338. [CrossRef]

20. Omar, N.A.S.; Fen, Y.W.; Matori, K.A. Europium doped low cost $\mathrm{Zn}_{2} \mathrm{SiO}_{4}$ based glass ceramics: A study on fabrication, structural, energy band gap and luminescence properties. Mater. Sci. Semicond. Process. 2017, 61, 27-34. [CrossRef]

21. Rasdi, N.M.; Fen, Y.W.; Omar, N.A.S.; Azis, R.S.; Zaid, M.H.M. Effects of cobalt doping on structural, morphological, and optical properties of $\mathrm{Zn}_{2} \mathrm{SiO}_{4}$ nanophosphors prepared by sol-gel method. Results Phys. 2017, 7, 3820-3825. [CrossRef]

22. Samsudin, N.F.; Matori, K.A.; Wahab, Z.A.; Liew, J.Y.C.; Fen, Y.W.; Aziz, S.H.A.; Zaid, M.H.M. Low cost phosphors: Structural and photoluminescence properties of $\mathrm{Mn}^{2+}$-doped willemite glass-ceramics. Optik 2016, 127, 8076-8081. [CrossRef]

23. Yang, B.; Yang, Z.; Liu, Y.; Lu, F.; Li, P.; Yang, Y.; Li, X. Synthesis and photoluminescence properties of the high-brightness $\mathrm{Eu}^{3+}$-doped $\mathrm{Sr}_{3} \mathrm{Y}\left(\mathrm{PO}_{4}\right)_{3}$ red phosphors. Ceram. Int. 2012, 38, 4895-4900. [CrossRef]

24. Babu, K.S.; Reddy, A.R.; Reddy, K.V.; Mallika, A.N. High thermal annealing effect on structural and optical properties of $\mathrm{ZnO}^{-S i O}{ }_{2}$ nanocomposite. Mater. Sci. Semicond. Process. 2014, 27, 643-648. [CrossRef]

25. Omar, N.A.S.; Fen, Y.W.; Matori, K.A.; Zaid, M.H.M.; Norhafizah, M.R.; Nurzilla, M.; Zamratul, M.I.M. Synthesis and optical properties of europium doped zinc silicate prepared using low cost solid state reaction method. J. Mater. Sci. Mater. Electron. 2016, 27, 1092-1099. [CrossRef]

26. Syamimi, N.F.; Matori, K.A.; Lim, W.F.; Aziz, S.A.; Hafiz, M.; Zaid, M. Effect of sintering temperature on structural and morphological properties of Europium (III) oxide doped willemite. J. Spectrosc. 2014, 2014, 1-9. [CrossRef]

27. Cortes, J.; Valencia, E. Phenomenological equations of the kinetics of heterogeneous adsorption with interaction between adsorbed molecules. Phys. Rev. B 1995, 51, 2621-2623. [CrossRef] [PubMed]

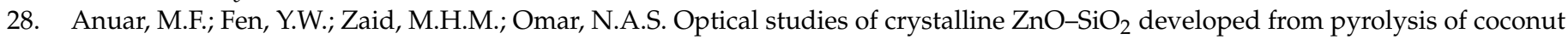
husk. Mater. Res. Express 2020, 7, 055901. [CrossRef]

29. Tarafder, A.; Molla, A.R.; Mukhopadhyay, S.; Karmakar, B. Fabrication and enhanced photoluminescence properties of Sm ${ }^{3+}$. Doped $\mathrm{ZnO}-\mathrm{Al}_{2} \mathrm{O}_{3}-\mathrm{B}_{2} \mathrm{O}_{3}-\mathrm{SiO}_{2}$ glass derived willemite glass-ceramic nanocomposites. Opt. Mater. 2014, 36, 1463-1470. [CrossRef]

30. Anuar, M.F.; Fen, Y.W.; Hafiz, M.; Zaid, M. Sintering temperature effect on structural and optical properties of heat treated coconut husk ash. Materials 2020, 13, 2555. [CrossRef]

31. Tauc, J.; Grigorovici, R.A.V. Optical properties and electronic structure of amorphous germanium. Phys. Status Solidi 1966, 15, 627-636. [CrossRef]

32. Fen, Y.W.; Yunus, W.M.M.; Yusof, N.A.; Ishak, N.S.; Omar, N.A.S.; Zainudin, A.A. Preparation, characterization and optical properties of ionophore doped chitosan biopolymer thin film and its potential application for sensing metal ion. Optik 2015, 126, 4688-4692. [CrossRef]

33. Engku Ali, E.A.G.; Matori, K.A.; Saion, E.; Aziz, S.H.A.; Zaid, M.H.M.; Alibe, I.M. Structural and optical properties of heat treated $\mathrm{Zn}_{2} \mathrm{SiO}_{4}$ composite prepared by impregnation of $\mathrm{ZnO}$ on $\mathrm{SiO}_{2}$ amorphous nanoparticles. Asm Sci. J. Spec. Issue 2018, 1, 75-85.

34. Lee, C.S.; Matori, K.A.; Ab Aziz, S.H.; Kamari, H.M.; Ismail, I.; Zaid, M.H.M. Fabrication and characterization of glass and glass-ceramic from rice husk ash as a potent material for opto-electronic applications. J. Mater. Sci. Mater. Electron. 2017, 28, 17611-17621. [CrossRef]

35. Khaidir, R.E.M.; Fen, Y.W.; Mohd Zaid, M.H.; Matori, K.A.; Omar, N.A.S.; Anuar, M.F.; Abdul Wahab, S.A.; Khirel Azman, A.Z. Addition of $\mathrm{ZnO}$ nanoparticles on waste rice husk as potential host material for red-emitting phosphor. Mater. Sci. Semicond. Process. 2020, 106, 104774. [CrossRef] 
36. Sahu, I.P.; Bisen, D.P.; Brahme, N.; Tamrakar, R.K. Photoluminescence properties of europium doped di-strontium magnesium di-silicate phosphor by solid state reaction method. J. Radiat. Res. Appl. Sci. 2015, 8, 104-109. [CrossRef]

37. Shaker, A.; Zekry, A. A new and simple model for plasma and doping and doping induced band gap narrowing. J. Electron. Devices 2010, 8, 293-299. 